\title{
Patronage of Ecotourism Potentials as a Strategy for Sustainable Tourism Development in Cross River State, Nigeria
}

\author{
Aniah, Eugene J. \\ Department of Geography and Regional Planning \\ University of Calabar, Calabar, Nigeria \\ E-mail: geneaniah@yahoo.com \\ Eja, E. I. \\ Department of Geography and Regional Planning \\ University of Calabar, Calabar, Nigeria \\ E-mail: ejako2007@yahoo.com \\ Otu, Judith E. \\ Department of Sociology \\ University of Calabar, Calabar, Nigeria \\ E-mail: judithesame@yahoo.co.uk \\ Ushie M. A. \\ Department of Sociology \\ University of Calabar, Calabar, Nigeria. \\ E-mail: ushiemike@yahoo.com
}

\begin{abstract}
Today, Obudu Ranch Resort is one of the tourism havens in the world which has attracted great number of visitors to Nigeria and Cross River State in particular. This resort has not only aided the development of existing tourism potentials but has equally transformed the livelihood of most communities in Cross River State through income generation, employment and also provision of basic social amenities such as electricity, water supply, road network among others in the area. This paper critically examine the level of domestic and international patronage of Obudu Ranch Resort between 2001-2008, tourist preference of the resort, major attraction and facilities in the resort, population threshold of the enclave communities within the study area and the purpose of tourists visit to the Ranch Resort. Chi-square was used in testing the stated hypothesis as regards to the amount expended by the tourist as fare to the ranch. Inspite of the tremendous facilities available in the Ranch Resort much is still needed to be done in other to boast the image of the Resort and also to attract high patronage of domestic and international tourists. Therefore, the hope of the masses and development of the Ranch Resort is rested on the government and the private sector.
\end{abstract}

Keywords: Ecotourism, Patronage, Tourism and Sustainable

\section{Introduction}

Tourism could be related to the Biblical story of the visit of the queen of Shebba to King Solomon. Tourism is seen as a leisure activity, which is international in character. Eboka (1999) described tourism as the movement of people to destinations outside their usual abode or residence on short-term bases. In the same vein, tourism is seen as a visit as well as the services industries create to satisfy the needs arising from movement within or across international boundaries temporary. In recent times, Ecotourism has attracted increasing attention in recent years not only as an alternative to mass tourism, but as a means of economic development and environmental conservation (Campbell, 2002). 
Ormsby et al (2006) opened that ecotourism venture have sustained the economy of most nations for example east African countries like Kenya, Tanzania and part of West Africa like Senegal. Ecotourism is mainly the interaction between the physical environmental features for leisure purposes. It is in this light the several thousand of people live their usual residencies to areas with friendly climate, coastal regions for hiking and trekking, surfing and swimming and the enjoyment of friendly ambience. Cross River State is endowed with great ecotourism potentials such as Obudu Ranch Resort, Water Falls, Warm Spring among others which have attracted both local and international tourists patronage.

In Cross River State, the green vegetation, the rising sun, escorting many people from the capital city of Calabar, through the mangrove swamps to the tropical virgin forests to Akamkpa, Ikom and Boki, then to the mountain savannah of Ogoja and Obudu. This great eco-tourism potentials has afford several tourists and visitors a unique opportunity to see the beauty of the physical features of an enticing bride called Cross River State. Today the overwhelmed, beautiful landscapes, colourful folks, an overwhelming serenity and the agreeable climate has made Obudu Ranch Resort a natural paradise. However, this paper critically assess the level of the patronage of Obudu Ranch Resort particularly as regards to domestic and international tourist patronage of the resort between 2001-2008, tourism facilities and attraction in Ranch Resort, reason for tourists preference of the ranch, population threshold of the area and purpose for their visit to the Ranch. To achieve the above stated research findings, two hypothesis were put forward thus:

$\mathbf{H}_{\mathbf{0}}$ : There is no significant difference between the number of tourists visiting Obudu Ranch Resort and the distance between Obudu and the tourist home.

$\mathbf{H}_{\mathbf{1}}$ : There is significant difference between the number of tourists visiting Obudu Ranch Resort and the distance between Obudu and the tourist home.

\section{Study area}

Obudu Ranch Resort is located at an altitude of 1,575 meters above sea level, and a unique temperature climate and vegetation with temperature ranging between $7^{0} \mathrm{c}-15^{\circ} \mathrm{c}$ all year round. It is a gold mine, anxiously wanting to be fully exploited. It is bounded to the north by Benue State, to the South by Ogoja local government area and the East by the Republic of Cameroon.

\section{Methodology}

This paper focus on patronage of ecotourism resort for sustainable tourism development in Cross River State using Obudu Ranch Resort as a case study. Data were collected in the field using Participatory Research Method (PRM), questionnaires, interview, field observation and library materials.

Three hundred and forty copies of questionnaires were administered to different tourists. While the management of the ranch resort were interview to ascertain the level of domestic and international of patronage of the ranch resort. However, participatory research method was adopted to help familiarize and also to have a focal group discussion with the different administrative cadre or staff in the ranch resort. Information concerning population threshold of the adjourning communities were collected from National population commission, Cross River State. However, the stated hypothesis was tested using chi-square to confirm the validity of the data collected in the field. The chi-square formula which is stated as:

$$
x^{2}=\frac{\left(f_{0}-f_{e}\right)^{2}}{f^{2}}
$$

Nevertheless, the chi-square was used to examine the variables in the sample population.

\section{Literature Review}

\subsection{Tourism in theory and practice}

Tourism in Nigeria today is not a new phenomenon. It is also considered as one of the most profitable industries with perhaps one of the lowest possible investment. The tourist industries in Nigeria is still fairly developed when compared to those found in other countries of both the developed and developing world.

Tourism has become a powerful vehicle of economic growth which has contributed to the socio-economic development of most countries of the world especially countries like Switzerland, Brazil, Thailand among others where tourism is the main stay of her economy. (Goswami, 1979).

An instance could be cited from Spain with 2-6 million dollars from foreign tourism in 1992, this figure represents two thirds of its invisible export for that year.

(Ukpana, 2005) has contended that "domestic tourism in developing countries is a phenomenon that has so far been under estimated in scientific literature". This statement applies to Nigeria almost more than any other country in view of the dearth of literature on this subject in the country. Among the few studies so far done on this topic with particular 
reference to Nigeria is one by $(\mathrm{Ojo}, 1978)$ in which he traced the historical development of tourism and recreation in Nigeria from the pre-colonial through colonial to the post colonial eras of the country. He also delued deeply into the present state of the industry in the country. Ojo concluded his study with an analysis of the attitude of Nigerians to tourism and recreation using Illorin as a case study. He concluded that there is a relationship between the individual's educational background and his desire to participate in tourism. Another important variable is the individual's level of awareness of the existence of a tourist resort. It is true that a tourist will be motivated to go to any particular resort only when he is attracted and the facilities of his choice are available in such a place. Broadly speaking, the hall mark of Obudu Cattle Ranch include:

1) Good weather/climate

2) Scenery

3) Amenities and accommodation

4) Historical and cultural features

5) Accessibility

6) Natural resources such as (the hill, fertile, land, different animal species etc).

Fine weather is one of the most important attraction of a tourist center. Good weather is important in tourism that it has been capitalized upon by such places that are blessed with a unique and peculiar kind of climate. It should be stressed that in the tropics, any area with a mild or temperature climate is preferred to areas with strictly tropical climate. The development of Obudu Cattle Ranch as a holiday resort can be explained mainly by its fine and exhilarating climate which is all year round.

A report of the cognizance survey of Obudu Cattle Ranch the cultural heritage of the people describes the place as "The best site in the world to constitute a game reserve..." (UNESCO, 1979).

Beautiful and unique national scenery have also continued to be a great fascination to tourists all over the world. To be able to attract tourist in appreciable numbers, sceneries like mountains, water fall, moorland etc should combine both age and physical splendor. The important of scenery in tourism has also emphasized by Coppock and Duffied, (1980) in observing the "scenery is the principle resource in formal outdoor recreation and that the appearance and perception and landscape are very important denominator in public enjoyment and country side. For tourists to visit any centres, the must be available facilities for lodging, swimming, recreation, amusement, games and spoils, viewing etc". This then brings out the importance of the third element of tourism. Increasingly, the holiday maker has demanded entertainment and recreational facilities in larger measures. What has come to be known as "development" has preoccupied the resort management.

(Robinson, 2006) went further to say that, putting green and bathing pools, theatres, cinemas, fun palace, chair lift etc are some of the amenities is the provision of lodging and food, loosely called accommodation. The importance of accommodation lies in the fact that most tourists visit particular sport simply because there is first class accommodation where food, sleep and other things could be obtained. Features of historical and or of culture interest also exert a strong pulling force for many tourists.

However, the incomparable Egyptian pyramid, cathedrals, temple, art galleries, musical festivals, long historical and cultural significance cities like Carro, Paris, London and other attract most tourist to this great areas.

In planning spatial behaviour (Lynch, 1975) state that "the likelihood of the person going to the particular place is a function of its attributes (resources) modified by the person's knowledge and attitude towards the attribute (perception) and further qualified by the availability of access to the place (accessibility)". By this, it implies that no matter the quality of a place, the person going there must first know that such a place exists. The physical relationship of any tourist center and the problem inadequate transport facilities which can clearly, affect the development of tourism e.g a resort can posses a much attraction and amenities that could have naturally attracted tourist, but because of accessibility, tourists will become rare bird in such a center.

Hall (2003) in his study of the impact of tourism discovered that tourism has become a significant source of foreign exchange revenue for many countries of the world. According to him, tourism activities in Maldives contributed 66.6 percent of the country's Gross Domestic Product (GDP) and accounted for 65.9 percent of its exports. According to Hall analyses, tourism industry in Vanuatu has contributed 47.0 percent of the country's GDP and 73.7 percent of its total export earnings. They went further to emphasize that thirteen (13) developed countries in Asia (Cambodia, Lao people's democratic Republic and Neps). Tourism accounted for more than 15 percent of export earnings.

There further stress that tourism alone contributed 43.5 percent of the export earnings of Fiji and one third of its GDP. Other small Islands such as Tonga and Vanuatu are dependent on tourism for half or more of their export earnings. Prentice (2007) in his study opines that tourism in China has provided a substantial contribution to its GDP, amounting 
to 13.7 percent in 2006. Taking full advantage of the potential of their natural and cultural tourist resources, countries in the greater Mekong sub-region are benefiting from the tourism industry. He went further to stress that in 2006, tourism in Cambodia and the Lao people's Democratic Republic accounted respectively for 22.3 and 21.4 percent of their total export earnings and contributed 19.6 and 9.3 percent respectively of the GDP.

\section{Research findings}

\subsection{Domestic and International Patronage of Obudu Ranch Resort}

The data obtained was base on domestic and international patronage of Obudu Ranch Resort. The data collected indicate that the total number of Nigerian visitors who visit the Ranch supersede that of foreign visitors as shown in Table 1. Table 2 also reveals that there is a progressive increase of tourist patronage of the resort from 2001-2008, this could be due to improvement in infrastructural development in the Ranch Resort. The data collected also indicate that 2008 recorded the highest domestic patronage of the Ranch Resort with a value 16.843 compared to international patronage which had 6727 as present in Table 1.

Data were also collected to show the amount expended by tourist as fare to the ranch as indicate in Table 2. Table 2 reveals that the choice of the site tend to be base on the cost as indicated by the number of respondents.

To confirm the validity of the stated hypothesis using the amount expended by the tourist as fare to the ranch, the result indicate a high significance level as the computed value was 82.31 while table value at 0.5 was 3.38 . Therefore, the null hypothesis $\left(\mathrm{H}_{0}\right)$ was rejected in favour of the alternatives hypothesis. Table 3 shows basic tourism attractions and facilities in Obudu Ranch Resort. These potentials are of great important to tourist, as there other the best satisfaction to different categories of tourist that visit the ranch resort.

\subsection{Major Tourism Attractions And Facilities In Obudu Ranch Resort}

The ranch resort affords many people a unique opportunity to see the beauty of the physical features of an enticing "bride" called Cross River State. The overwhelming beautiful landscapes, colourful folks, agreeable climate and vegetation welcome visitors to the highland of the race. However, there are different facilities provided for tourist at the ranch resort. However, these facilities range from conference centre, education centre, main restaurant, cable car, traditional huts, fire station, honey moon, warehouse, new reception zone among others. Most of these facilities also provide other sub units such as library/research, shop, storage convenience, tea rooms, changing rooms for male and female among others. The provision of all these facilities by the government and private sector is in a bid to boost the image of the ranch and also to create an enabling environment for visitors wishing to patronage the resort.

Table 3 indicate reasons why tourists preferred visiting the Ranch Resort. The data collected reveals that most people are attracted to the climatic condition of the Ranch Resort as it had a value $35.6 \%$ follow by the facilities in the Resort with $24.8 \%$. Although other factors such as scenery with a value $21.7 \%$, popularity of the Resort $10.8 \%$ are also responsible for why people visit the Ranch. However, the data collected in table 4 reveals that almost everybody visit the Ranch due to climatic and weather condition and scenery of the environment. Other factors such as availability of facilities with $24.8 \%$, popularity of the resort $10.8 \%$ and others where also responsible why certain persons visit the ranch.

The ranch which has a temperate weather condition is very unique and has different characteristic of this part of the world. Table 4 shows the population threshold of the various communities within the study area. The population of the various communities was obtained from development in Nigeria 2003 and the Quash Bully \& Association 2008. The population indices obtained reveals a fluctuation in population of the different communities such as Anape, Okpazawge, Kogol, Keji-Ukwu, Okwamu and Apeh-Ajil respectively as shown in the table 4.

The data collected also reveals that $10.5 \%$ of the tourists are researchers, $25.2 \%$ are for Business, $8.5 \%$ visit the ranch for the purpose of attending conferences.

\section{Conclusion}

Tourism development in Cross River State is a phenomenon which has impacted significantly to the livelihood of most Nigerian in general and Cross River State in particular through income generation, employment and has also transform most of the enclave (rural) communities endowed with these laudable potentials into a natural paradise through the provision of basic amenities and infrastructures such as road network, electricity, pipe borne water amongst others. Today Obudu Cattle Ranch is a distributive hub in West Africa and has attracted domestic and international tourists and visitors all over the world into Nigeria in general and Cross River State in particular hence making Cross River State a holiday town. However, the sustainability (future used) of the Ranch Resort lies in the hands of all the stakeholders such as private individual, the government and the local people whose livelihood depend solely on the environment of this great industry and potentials. Therefore, the private individual and government must advocate programmes and policies that will enhance the livelihood of these local communities within these areas so as to salvage environmental problems such as unemployment, poverty, theft among others capable of disorganizing the entire ecosystem and the ranch resort in particular. 


\section{References}

Aniah, E. J. and Eja, E. Iwara. (2005). Tourism Development in Cross River State, Nigeria: A compendum of tourist sites and potential tourism areas. Calabar Journal of Liberal Studies, Vol.8, No.2. pp. 51-78.

Aniah, E. J. and Eja, E. Iwara. (2005). An Exposition and Analysis of Tourist Sites in Nigeria. Calabar Journal of Literary Studies, Vol. \& No.1, pp 139-157.

Aniah, E. J. Eja, E. Iwara and Edu, E. (2007). Tinapa Tourism and Business Resort, a model for the socio-economic development of Cross River State: Constraint and Temporal Perspectives. Tropical Focus, Vol. \& No.3, pp. 131.

Areola. (1976). Recreational landuse in Nigeria. Geographical Journal, Vol.19(2), pp.227-236.

Baniforde and Robinson. (1976). Robinson. (1978). Geography to transport MacDonald and Evans.

Campbell, L. M. (2002). Ecotourism in rural developing communities. Annals of Tourism Research, 26(3) pp 534-553.

Coppock, J. P. and Duffiod, B. A. (1980). Recreation in the country side, A spatial analysis. Economic Geography.

Deaby, G. F. (1966). Impact to tourist facilities on its interland.

Eboka, O. A. (1999). Man and Leisure: A Philosophy of Recreation. C. K Bright Bill (ed) Green Wood Press.

Gray, W. and Liguor, S. C. (2001). Hotel and motel Management and Operations. Third Edition, Singapore: Prentice Hall Simon and Schister (Asia) pte Ltd.

Hall, C. M. (2003). Politics and place: An analysis of power in tourism communities, Oxford, England, 99-114.

Hugget, R. J. (1980). Systems Analysis in Geography (Contemporary Problems in Geography). Oxford University Press, Oxford.

Kigoth, W. (2000). Gaining Ground. Business in Africa \& (1) pp. 16-17.

Larry, E. (2005). The Cross River State Tourism Vision and Policy Mofinews, 3 (44, 48-49).

Lucas, R. (2003). Anticipating and Adjusting to the National Minimum Wage in the Hospitality and Clothing Industries Policy Studies, 24(1), 33-50.

Lynch, B. C. (1975). Tourism Economic Physical and Social Impacts. Routledge London.

Marrison, A. (2004). The Family Business in Tourism and Hospitality. Wallingford. CABI.

Mason, D. A. (2004). Tourism Environment and Development. East Bourn Manor Park Press.

Nigeria Tourism Development Corporation. (2007). Nigeria Tourism Development Corporation (NTDC) Guide for Local Authorities on developing sustainable tourism.

Ojo, G. J. (1976). Nigeria National park and related reserves.

Olojessusi, F. (2005). The Constraint of Tourism development in Nigeria. The Case Study of Bauchi and Ogun State NISER Ibadan.

Ormsby, A. and Mannle, K. (2006). Ecotourism benefits and the role of local guides at Masola National park, Madagascar. Journal of Sustainable Tourism, 14(3), pp 271-287.

Pearce, D. (1997). Competitive Destination Analysis. Southeast Asia Journal of Travel Research, 35(4) 16-24.

Prentice, R. (2007). Strategic management for tourism Countries: bridging the gaps, tourism, 23, 363-377.

Robinson, H. (2006). Geography of Tourism. London: MacDonald and Evans.

Ukpana, S. (2005). Tourism Development in Nigeria. Lagos: Macmillan.

UNESCO. (1979). Final report of sub-regional training. Workshop on environmental education programme Nekedem, Owerri. 
Table 1. Patronage of Domestic and International Tourist between 2001-2008 in Obudu Ranch Resort

\begin{tabular}{|c|c|c|c|c|}
\hline Year & $\begin{array}{c}\text { Number of Visitors } \\
\text { Nigerian }\end{array}$ & \% of Total & $\begin{array}{c}\text { Number of Visitors } \\
\text { Foreigner }\end{array}$ & \% of Total \\
\hline 2001 & 1231 & 1.88 & 253 & 1.39 \\
\hline 2002 & 1613 & 2.47 & 373 & 2.05 \\
\hline 2003 & 3074 & 4.70 & 936 & 2.95 \\
\hline 2004 & 6307 & 9.65 & 1312 & 7.07 \\
\hline 2005 & 9715 & 14.87 & 3117 & 17.16 \\
\hline 2006 & 12,091 & 18.50 & 4922 & 27.10 \\
\hline 2007 & 14,467 & 21.14 & 6727 & 37.04 \\
\hline 2008 & 16,843 & 25.77 & $\mathbf{1 8 , 1 6 1}$ & \\
\hline Total & $\mathbf{6 5 , 3 4 1}$ & & & \\
\hline
\end{tabular}

Source: Resort Management 2008

Table 2. Amount Suspended by Tourist as Fare to the Ranch

\begin{tabular}{|l|c|c|}
\hline \multicolumn{1}{|c|}{ Amount (N) } & Response Frequency & \% of Sample \\
\hline Below 5,000.00 & 106 & 41.9 \\
\hline $5,000.00-14,000.00$ & 63 & 25.82 \\
\hline $15,000.00-25,000.00$ & 36 & 14.75 \\
\hline $25,000.00-34,000.00$ & 28 & 9.24 \\
\hline $35,000.00$ and above & 81 & 12.71 \\
\hline & $\mathbf{3 1 4}$ & \\
\hline
\end{tabular}

Source: Fieldwork 2008

Table 3. Tourist's Preference of Obudu Ranch Resort

\begin{tabular}{|c|l|c|c|}
\hline S/N & \multicolumn{1}{|c|}{$\begin{array}{c}\text { Reasons for preference Obudu Ranch } \\
\text { Resort }\end{array}$} & No of Respondent & Percentage \\
\hline 1 & Climate/weather & 68 & 35.6 \\
\hline 2 & Scenery & 78 & 21.7 \\
\hline 3 & Availability of facilities & 34 & 24.8 \\
\hline 4 & Popularity of the resort & 22 & 7.0 \\
\hline 5 & Others & $\mathbf{3 1 4}$ & \\
\hline & TOTAL & & \\
\hline
\end{tabular}

Source: Field Work 2008 
Table 4. Population Threshold of Communities in Obudu Ranch Resort

\begin{tabular}{|c|c|c|c|c|c|}
\hline \multirow[b]{2}{*}{$\mathbf{S} / \mathbf{n}$} & \multirow[b]{2}{*}{ Village } & \multicolumn{2}{|c|}{$2003 *$} & \multicolumn{2}{|c|}{$2004+$} \\
\hline & & Population & $\begin{array}{c}\text { Average } \\
\text { Household size }\end{array}$ & Population & $\begin{array}{c}\text { Average } \\
\text { Household size }\end{array}$ \\
\hline 1 & Anape & 336 & 8 & 958 & 22 \\
\hline 2 & Okpazawge & 225 & 9 & 693 & 19 \\
\hline 3 & Kegol & 286 & 13 & 770 & 20 \\
\hline 4 & Keji-Ukwu & 221 & 13 & 678 & 24 \\
\hline 5 & Okwamu & 112 & 8 & 444 & 18 \\
\hline 6 & Apeh-Ajili & 165 & 15 & 567 & 28 \\
\hline & & 1,345 & 11 & 4110 & 22 \\
\hline
\end{tabular}

Source: * Development in Nigeria 2003

+ Quash Bully \& Associates 2008

Table 5. Purpose of Tourist visit to the Ranch

\begin{tabular}{|l|c|c|}
\hline Purpose of visit & No of respondents & Percentage \\
\hline Business & 79 & 25.2 \\
\hline Leisure & 53 & 16.9 \\
\hline Holiday & 108 & 34.4 \\
\hline Research & 33 & 10.5 \\
\hline Conference & 27 & 8.6 \\
\hline Any other (specify) & 14 & 4.5 \\
\hline Total & $\mathbf{3 1 4}$ & $\mathbf{1 0 0}$ \\
\hline
\end{tabular}

Source: Field Work 2008 


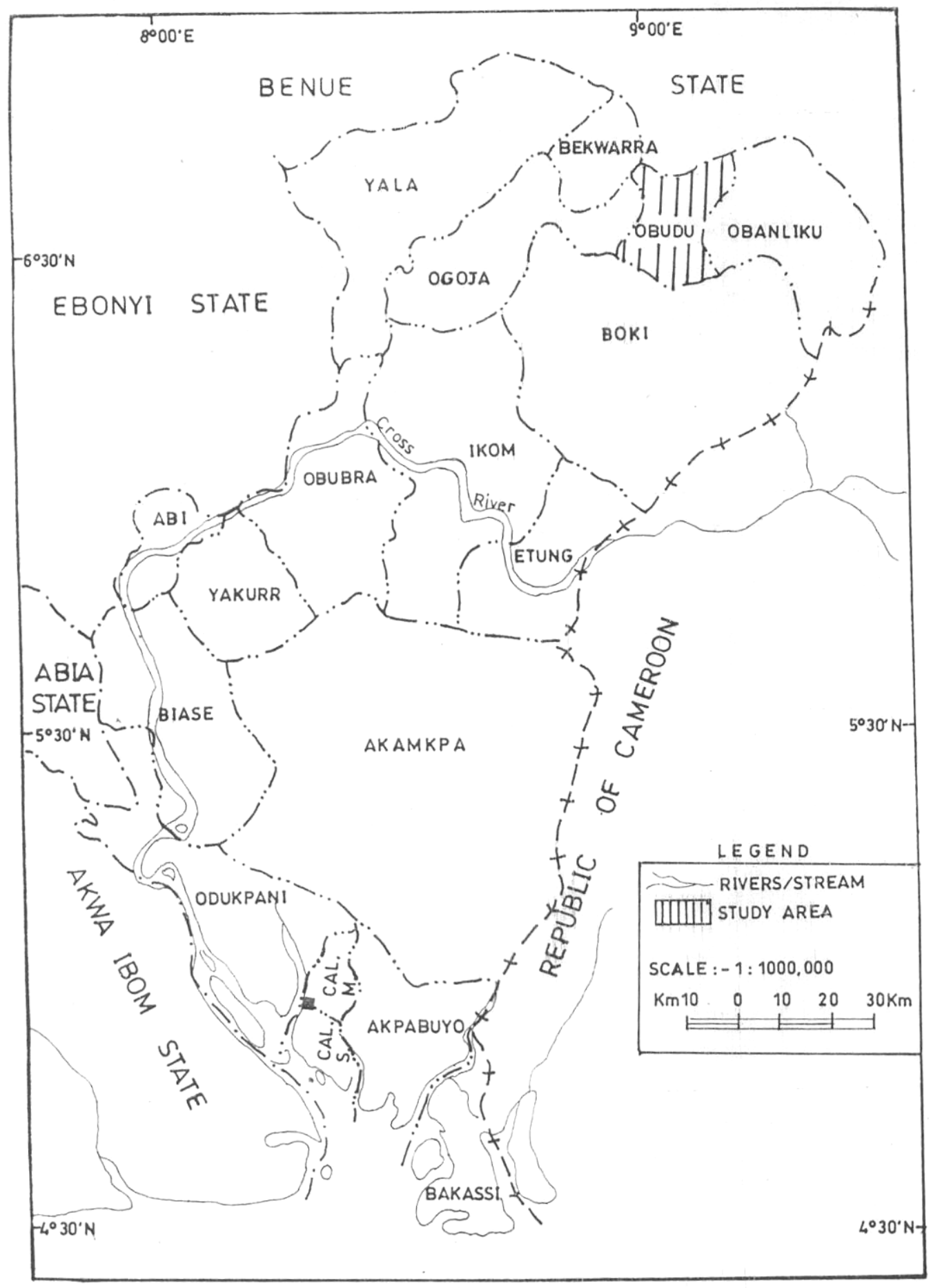

FIG. Map of Cross River State showing study area

Figure 1. Map of Cross River State showing study area 